Review

\title{
Research Progress of Desertification and Its Prevention in Mongolia
}

\author{
Xiya Liang ${ }^{1,2}$, Pengfei Li ${ }^{1, * \mathbb{D}}$, Juanle Wang ${ }^{2,3}, * \mathbb{D}$, Faith Ka Shun Chan ${ }^{4,5} \mathbb{D}$, Chuluun Togtokh ${ }^{6}$, \\ Altansukh Ochir ${ }^{7}$ (D) and Davaadorj Davaasuren ${ }^{8}$
}

1 College of Geomatics, Xi'an University of Science and Technology, Xi'an 710054, China; liangxy@lreis.ac.cn

2 State Key Laboratory of Resources and Environmental Information Systems, Institute of Geographic Sciences and Natural Resources Research, Chinese Academy of Sciences, Beijing 100101, China

3 Jiangsu Center for Collaborative Innovation in Geographical Information Resource Development and Application, Nanjing 210023, China

4 School of Geographical Sciences, Faculty of Science and Engineering, University of Nottingham Ningbo China, Ningbo 315100, China; Faith.Chan@nottingham.edu.cn

$5 \quad$ Water@Leeds Research Institute \& School of Geography, University of Leeds, Leeds LS2 9JT, UK

6 Institute for Sustainable Development, National University of Mongolia, Ulaanbaatar 14201, Mongolia; chuluunjim@yahoo.com

7 Environmental Engineering Laboratory, Department of Environment and Forest Engineering, National University of Mongolia, Ulaanbaatar 210646, Mongolia; altansukh@num.edu.mn

8 School of the Art \& Sciences, National University of Mongolia, Ulaanbaatar 14201, Mongolia; davaadorjd@gmail.com

* Correspondence: pengfeili@xust.edu.cn (P.L.); wangj1@igsnrr.ac.cn (J.W.); Tel.: +86-132-7926-3028 (P.L.); +86-10-6488-8016 (J.W.)

check for updates

Citation: Liang, X.; Li, P.; Wang, J.; Shun Chan, F.K.; Togtokh, C.; Ochir, A.; Davaasuren, D. Research Progress of Desertification and Its Prevention in Mongolia. Sustainability 2021, 13 , 6861. https://doi.org/10.3390/ su13126861

Academic Editor: Luca Salvati

Received: 12 May 2021

Accepted: 15 June 2021

Published: 17 June 2021

Publisher's Note: MDPI stays neutral with regard to jurisdictional claims in published maps and institutional affiliations.

Copyright: (c) 2021 by the authors Licensee MDPI, Basel, Switzerland. This article is an open access article distributed under the terms and conditions of the Creative Commons Attribution (CC BY) license (https:// creativecommons.org/licenses/by/ $4.0 /)$.
Abstract: Mongolia is a globally crucial region that has been suffering from land desertification. However, current understanding on Mongolia's desertification is limited, constraining the desertification control and sustainable development in Mongolia and even other parts of the world. This paper studied spatiotemporal patterns, driving factors, mitigation strategies, and research methods of desertification in Mongolia through an extensive review of literature. Results showed that: (i) remote sensing monitoring of desertification in Mongolia has been subject to a relatively low spatial resolution and considerable time delay, and thus high-resolution and timely data are needed to perform a more precise and timely study; (ii) the contribution of desertification impacting factors has not been quantitatively assessed, and a decoupling analysis is desirable to quantify the contribution of factors in different regions of Mongolia; (iii) existing desertification prevention measures should be strengthened in the future. In particular, the relationship between grassland changes and husbandry development needs to be considered during the development of desertification prevention measures; (iv) the multi-method study (particularly interdisciplinary approaches) and desertification model development should be enhanced to facilitate an in-depth desertification research in Mongolia. This study provides a useful reference for desertification research and control in Mongolia and other regions of the world.

Keywords: land degradation; spatiotemporal changes; driving factors; prevention; research methods

\section{Introduction}

Land degradation, a major environmental issue in the world [1,2], refers to the process during which the terrestrial ecosystem is being destroyed. The process results in a deterioration of land quality as well as a fundamental change of physical and chemical soil properties under the influence of unfavorable natural factors and human activities [3,4]. Land degradation in arid, semi-arid, and sub-humid regions is specifically termed as desertification [5-7]. Land desertification has become a major environmental problem that severely constrains the sustainable development of human society in the 21st century [8]. 
Nowadays, over 100 countries and more than 1 billion people in the world are facing the threat of desertification $[9,10]$. It has attracted great attention from the general public, government, and research community [11,12]. The subgoal 15 of the United Nations Sustainable Development Goals (SDGs) (SDG 15) indicates that it is necessary to protect, restore, and promote the sustainable use of terrestrial ecosystems and to achieve a zero growth of land degradation (Land Degradation Neutrality, LDN) by $2030[13,14]$. Serious land desertification in dryland areas forms one of the main challenges to the realization of the above goal. It is thus necessary to study and assess desertification risks and take appropriate measures to prevent desertification in the world [15].

Desertification is particularly widespread in arid and semiarid regions, as these areas are subject to water scarcity and comparatively sensitive to climate change and human interventions [16]. Among those regions, East Asia is one of the key areas that suffer from different levels of desertification. In particular, northwestern China and Mongolia have been widely recognized as severely desertified areas in East Asia [17,18]. Mongolia is one of the most prominent regions in the world facing the threat of land degradation. Due to the dry climate, land degradation in Mongolia is dominated by desertification [7]. Since the 1990s, Mongolia's land desertification developed rapidly and has not yet been well controlled [19]. As of 2017, over 76\% of Mongolia's land has suffered varying degrees of desertification, which increased from the northeast to the southwest [20-22]. The desertification is also currently spreading at a significant rate toward high-quality eastern grasslands such as the Dornod and Khentii grasslands [22]. Severe desertification does not only hinder the development of the fundament of Mongolia's national economy (animal husbandry) but also poses a major threat to the ecological environment within and around the region [19]. An in-depth understanding of Mongolia's desertification is not only beneficial for Mongolia's ecological and socioeconomic development but is also of great significance to the ecological protection of northeast Asia and other parts of the world.

In this paper, we aimed to review and investigate the desertification and its prevention in Mongolia. Based on an extensive review of literature, we systematically summarized the recent progress made in the desertification research and control in Mongolia. The limitations in previous studies and future research needs were also discussed to provide a reference for future desertification research in Mongolia and other parts of the world.

\section{Materials and Methods}

Mongolia $\left(87.9^{\circ} \mathrm{E}-119.9^{\circ} \mathrm{E}, 41.7^{\circ} \mathrm{N}-61.6^{\circ} \mathrm{N}\right)$ is located in the Mongolian Plateau, bordering China to the east, south, and west, and Russia's Siberia to the north (Figure 1). The land area is approximately 1.56 million $\mathrm{km}^{2}$. The altitude is high in the west and low in the east, with an average altitude of $1580 \mathrm{~m}[23,24]$. Mongolia is within a typical continental climate zone, with an average annual precipitation of $200-300 \mathrm{~mm}$. The precipitation is mainly concentrated in summer, with the concentration being more prominent in the north than in the south [19]. According to the aridity index (P/ETP) provided by the Food and Agriculture Organization of the United Nations, Mongolia is an arid (P/ETP: 0.05-0.20) and semi-arid (P/ETP: 0.20-0.50) area [25]. Soil types in Mongolia mainly include alpine meadow permafrost, mountain forest meadow soil, black soil, chestnut soil, and other soil types $[19,26]$. Vegetation types, from north to south, consist of alpine meadow, virgin forest steppe, steppe, and other vegetation types [27]. Mongolia's main economic industries include animal husbandry, mining, and the service sector. Pasture animal husbandry is a traditional industry in Mongolia, forming the fundament of Mongolia's economy. Half of the Mongolian people are engaged in the animal husbandry [28]. However, animal husbandry production is dominated by natural stocking, which is greatly affected by environmental change, e.g., desertification. Desertification has seriously threatened the eco-environment and affected the sustainable development of animal husbandry [19]. 


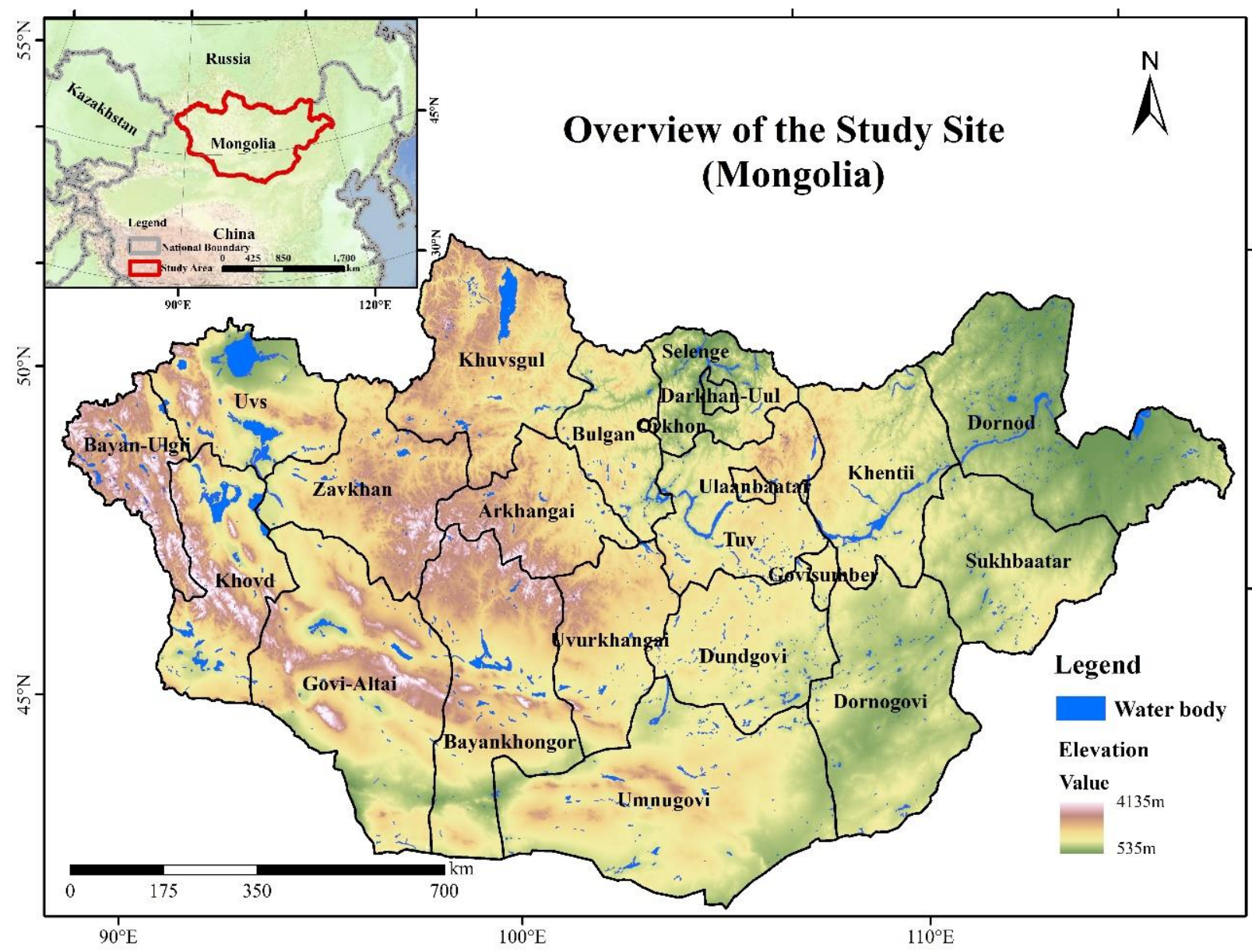

Figure 1. Overview of the study site, mainly showing the location, topography, and administrative divisions of Mongolia.

Based on an extensive review of the Chinese and English literature related to the desertification in Mongolia, we investigated spatiotemporal patterns, driving factors, prevention measures, and research methods of Mongolia's desertification. The literature search was conducted from November 2019 to March 2020 through the China National Knowledge Infrastructure (CNKI) database and Google Scholar using the keywords "Mongolia" and "Desertification" or "Land degradation." Sixty-two publications were acquired, including 13 Chinese papers and 49 English papers. The first study was published in 1996. The number of papers published was fewer than four per year between 1996 and 2014 and began to increase in 2015 (Figure 2a). Over 10 papers were published in 2018 and 2019, indicating that Mongolia's desertification has recently received increasing research attention. Desertification research methods comprised the topic for 41 of the 62 publications, while desertification prevention formed the topic of 12 publications. Spatiotemporal distribution/changes of desertification and its driving factors formed the research focus of 22 and 28 publications, respectively (Figure $2 \mathrm{~b}$ ). 

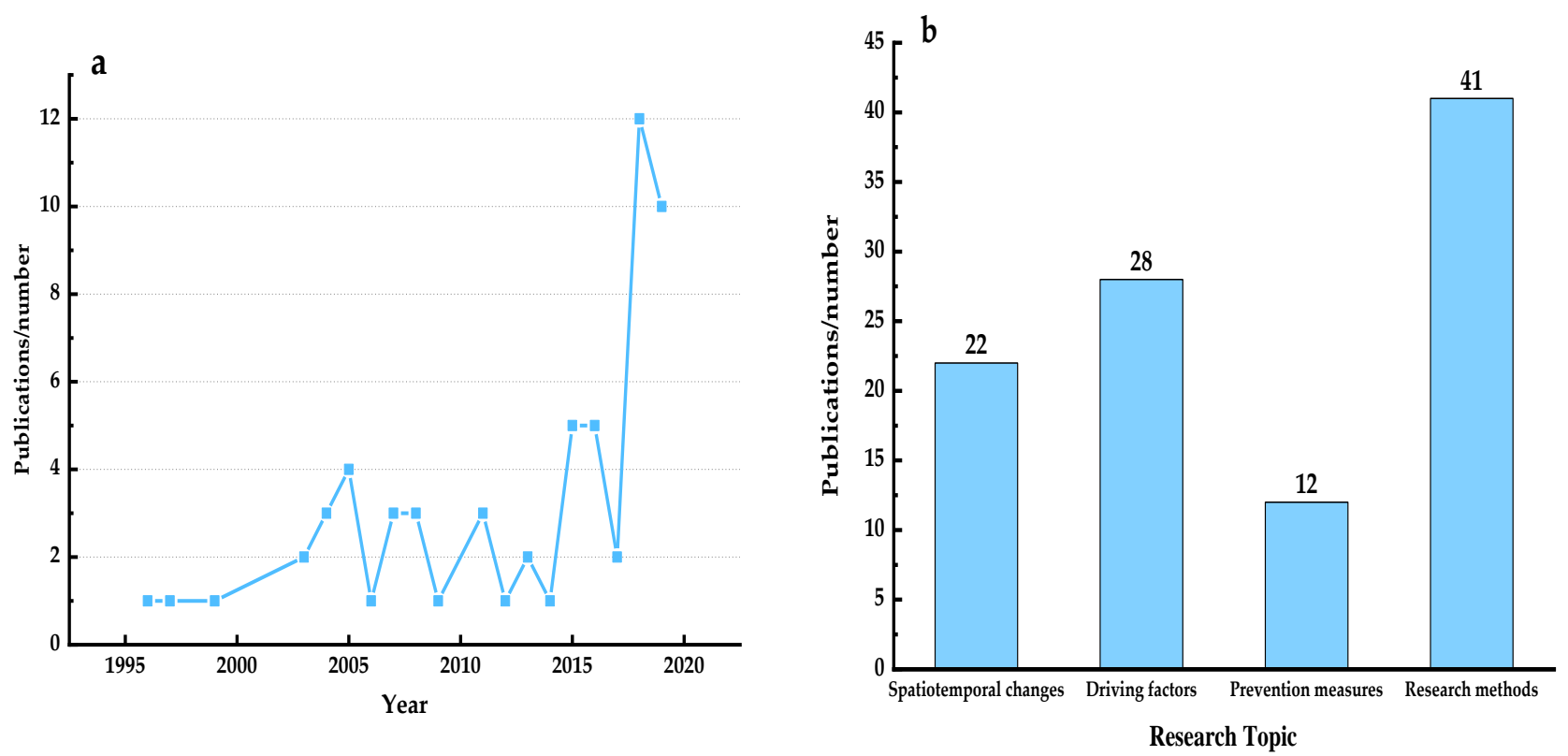

Figure 2. (a) The number of publications on desertification in Mongolia published since 1996; (b) the number of publications associated with each of the four research topics (i.e., spatiotemporal changes, driving factors, prevention measures, and research methods).

\section{Research Progress of Desertification and its Prevention in Mongolia}

\subsection{Spatiotemporal Changes of Desertification}

With regard to the temporal changes, desertification in Mongolia began in the 1960s and intensified after 1990 [19]. Although prevention measures have been implemented since the 1990s, land degradation remains the dominant trend in the land cover change [20]. From 1970 to 2005, the forest area of Mongolia decreased by $330.5 \mathrm{~km}^{2}$, and the steppe area also showed a decreasing trend. The area of bare land expanded in the unused land, and grassland retreated toward the sandy land [29]. The desertification monitoring data from 2003 to 2017 showed that extremely severe and severe desertification accounted for $23.17 \%$ and $27.53 \%$ of Mongolia's land area, respectively. This means that over $50 \%$ of the country's land area suffered from serious desertification [21]. In all, Mongolia's land desertification developed rapidly and has not yet been well controlled.

Through literature review, interviews, and historic measurement data Buren [19] found that the spatial changes of Mongolia's desertification were mainly distributed in the steppe and Gobi areas. In addition, Buren also found that desertification was more serious around lakes, rivers, cities, and sumu (sumu is an administrative-territorial unit-like district in Mongolia) [19]. Based on the $500 \mathrm{~m}$ Moderate-Resolution Imaging Spectroradiometer (MODIS) data, Chen et al. [21] analyzed the distribution pattern of desertification in Mongolia from 2003 to 2017. They found that the degree of desertification in Mongolia gradually increased from northeast to southwest, with extremely severe and severe desertification land mainly distributed in the Gobi and desert steppe in southwestern Mongolia, including nine provinces such as Dornogovi, Umnugovi, Bayankhongor, and Govi-Altai (Figure 1). Based on the $30 \mathrm{~m}$ land cover data, Wang et al. [20] studied the land degradation process in Mongolia from 1990 to 2015. The results showed that the degree of land degradation in Mongolia gradually increased from northeast to southwest (Figure 3), which was consistent with the findings of Chen et al. [21]. In addition, they found that the newly increased land degradation gradually expanded toward the northern border area of Mongolia. Most studies showed that desertification expanded in Mongolia, but Wang et al. [30] found that the areas of desert did not change dramatically. 

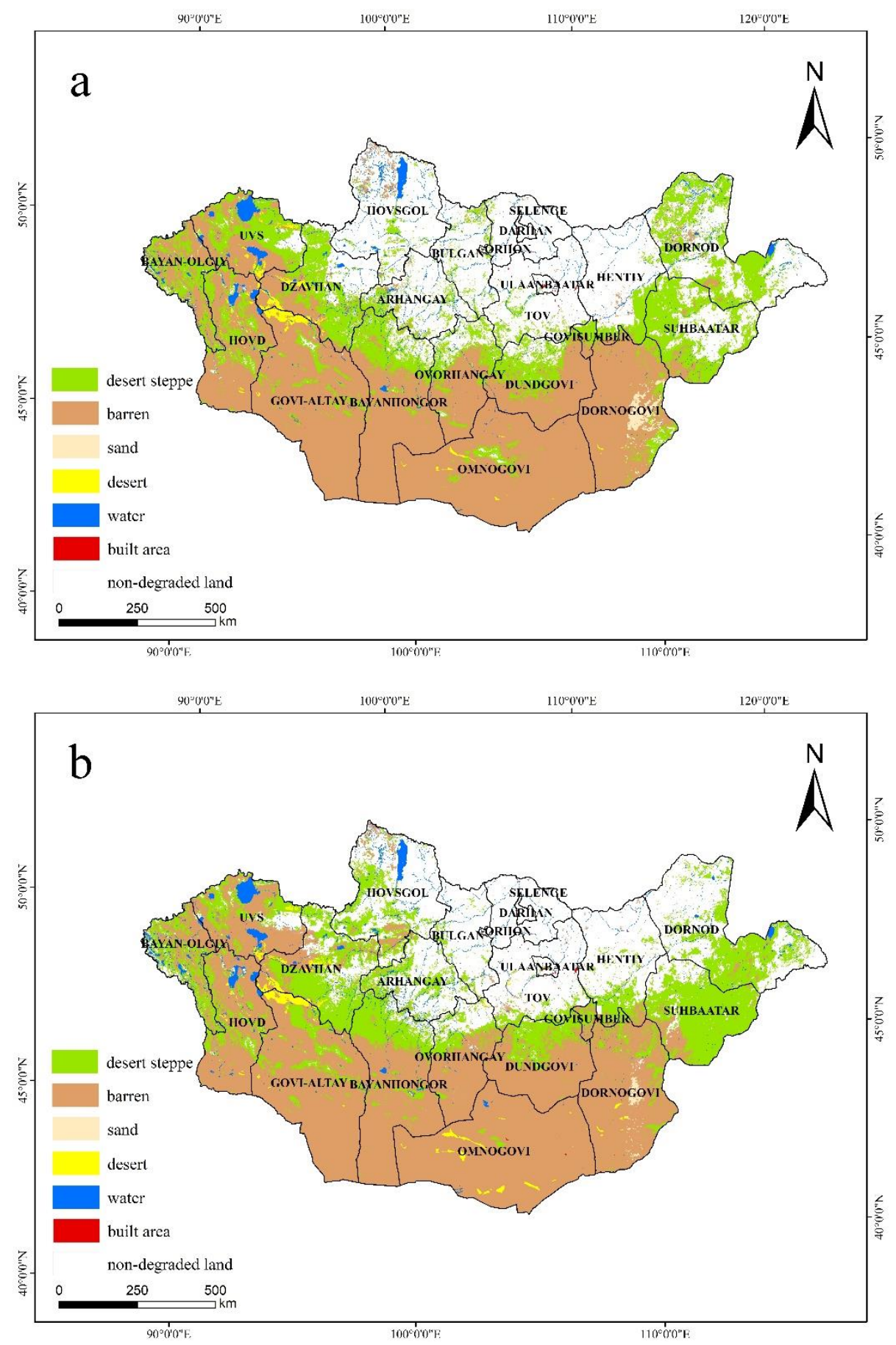

Figure 3. Cont. 


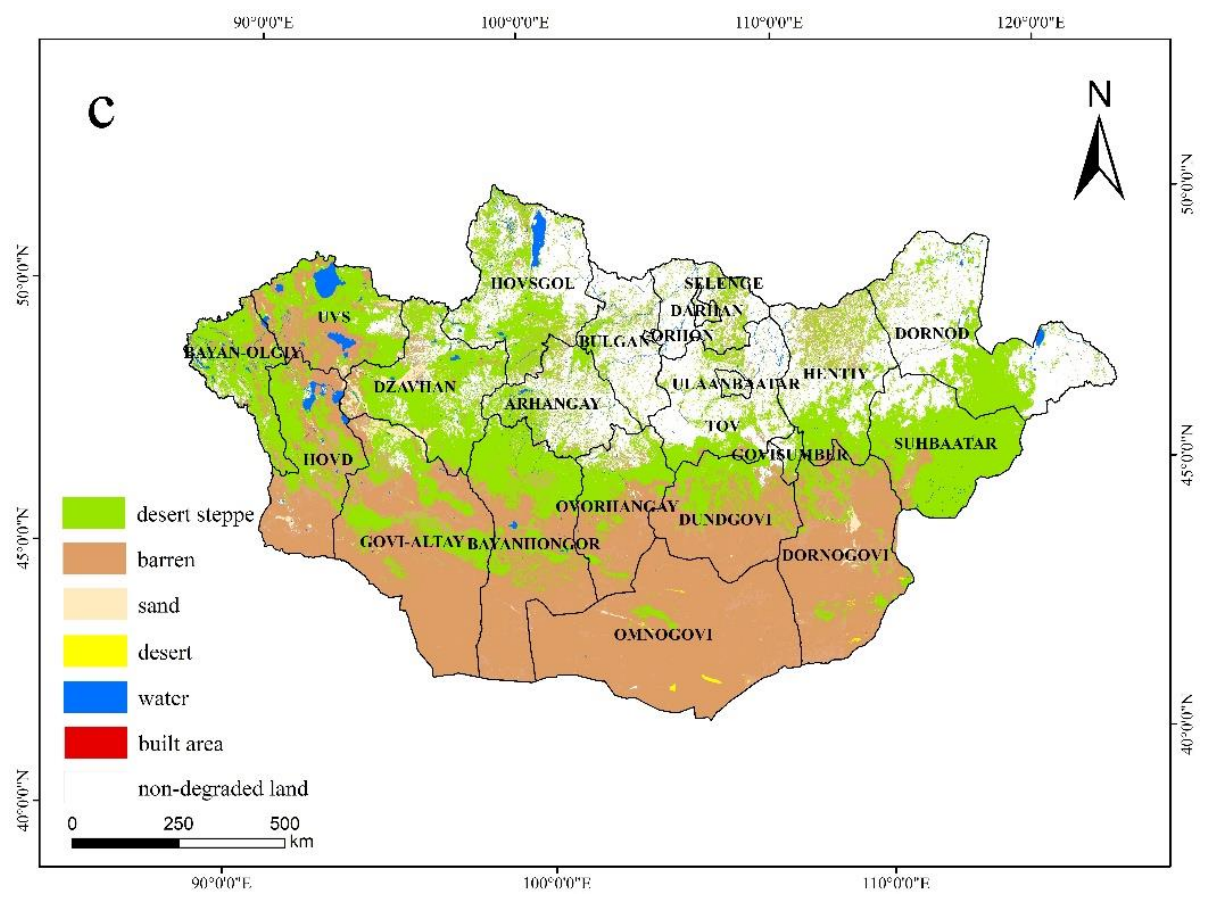

Figure 3. Land cover types of Mongolia in (a) 1990, (b) 2010, and (c) 2015. [20].

Remote sensing data have been widely applied in the desertification monitoring in Mongolia. Previous studies on land desertification monitoring were mostly conducted based on the MODIS data [31-33], the United States National Oceanic and Atmospheric Administration Advanced Very High-Resolution Radiometer (NOAA-AVHRR) data [34], European Space Agency (ESA) land cover data [29], and Landsat data [35]. The spatial resolution of these data for the whole Mongolia study is generally low, which constrains the accuracy of the analysis results and an in-depth process understanding of desertification. An improvement in the spatiotemporal resolution and accuracy of the data is necessary. In addition, previous studies have mainly investigated the desertification changes before 2015 [20,24,29,34-36], and timely desertification monitoring results and data products are still lacking. Therefore, it is necessary to carry out more timely and high-resolution research on the spatiotemporal changes of desertification to provide reference for desertification prevention and control.

Concerning future desertification changes, climate modeling showed that the temperature during the plants' growing period in arid regions of Asia (including Mongolia) will increase by an average of approximately $2.9^{\circ} \mathrm{C}$ from 2006 to 2100 , but the annual precipitation will only increase by approximately $0.1 \mathrm{~mm}$ [37]. Climate change exacerbates regional drought and inhibits the growth of vegetation. This eventually leads to the aggravation of desertification $[37,38]$. Desertification, in turn, affects the regional climate, which alters the regional water balance and surface energy balance as well as leads to a weakened monsoon circulation and increased surface temperature [39-41]. Therefore, Mongolia's desertification and future climate change may promote each other, increasing the difficulty and cost of desertification prevention. Future research is needed to further clarify the interactions between desertification and climate change and to explore the spatiotemporal patterns and driving mechanisms of desertification. The research results will provide a useful reference for the control of desertification in Mongolia and other parts of the world.

\subsection{Driving Factors of Desertification}

Desertification in Mongolia is a result of the combined effects of natural and human factors [42] (Table 1). The natural driving factors primarily refer to climate change, specifically including increased temperature and decreased precipitation. Since the 1980s, the 
average temperature in Mongolia has risen by $1.5-2.5^{\circ} \mathrm{C}$, which is 2.3 times the global average level. Precipitation in the southern and central regions of Mongolia has decreased, which has intensified the desertification [43]. Human-related driving factors mainly include overgrazing, changes in herd structure, and grazing systems. In the early 1990s, Mongolia reformed its economic system and implemented the policy of "privatization of livestock." In pursuit of economic benefits, herders rapidly increased the livestock numbers, leading to serious damage and direct degradation of steppe $[19,20]$. In addition, Mongolia's grazing system was dominated by seasonal and fixed-point grazing. A rotational grazing system has not been well established because of too much livestock. As a result, there was not enough recovery time for grassland vegetation, resulting in an unbalanced relationship between grassland plant diversity and livestock structure diversity. This problem further exacerbated the degradation of grassland [43,44]. At the same time, other human factors also initiated and/or exacerbated the desertification of local regions of Mongolia, such as mining industry development, irrational use of natural resources, and urbanization $[20,28,34,45]$.

The influencing factors of desertification are spatially variable, and their relative contributions also vary among regions. For example, Sukhbaatar Province is windy, which is one of the main factors influencing local desertification [44,46]. In forest areas, fire destroys vegetation coverage and increases desertification in the area [47], which is one of the important natural driving factors for desertification. On the steppe, overgrazing is an important human driving factor for desertification. In the mining area of southern Mongolia, mineral mining and road erosion induced by the transport of minerals are two human factors of desertification [42,45]. In the arable land, soil erosion induced by agricultural production is the leading human factor for regional desertification [45]. The contributions of different factors need to be well evaluated for different parts of Mongolia, which will be beneficial for understanding the process and control of desertification.

Some studies have explored the relative contributions of factors affecting desertification in different regions of Mongolia. Filei et al. [47] studied the relationship between vegetation dynamics and climatic factors and analyzed the impact of natural and human factors on land degradation in Mongolia from 1982 to 2016. They demonstrated that the decrease in precipitation and increase in temperature were the main reasons for the degradation of vegetation in Mongolia; in particular, precipitation during the vegetation growth period was found to be the key factor that determines the dynamic changes in the vegetation of Mongolia [47]. In contrast, Tian et al. [48] studied samples collected from lakes in central Mongolia and found that the transition to a market economy since the 1990s has caused severe land degradation. It was concluded that human factors were the dominant factors that cause ecosystem changes in the study area [48]. Using the net primary productivity (NPP) as an indicator, Yang et al. [49] quantitatively assessed the relative contribution of climate variation and human activities in Mongolia from 2000 to 2013 and found that human activities dominated degradation in Mongolia.

The above contradictory findings on the contribution of natural and human factors may be attributed to the difference in research scales. For example, Tian et al.'s [48] research was concentrated on the lake area. Their conclusions may not be applicable to other regions of Mongolia. This also implies that there are different leading factors of land degradation in different regions, and in-depth research should be carried out at multiple scales. In addition, Filei et al.'s study was conducted across 1982-2016, while Yang et al.'s study covered the period of 2000 to 2013 [47,49]. The economic reform in the early 1990s may account for the dominance of human activities after 2000. That is to say, the natural and social development conditions were different for these two studies, possibly accounting for the difference in their findings. Future studies should further consider the relative contributions of different factors based on the multi-scale analysis.

Decoupling research is able to clarify the impacts of different factors on desertification and quantify the relative contributions of natural and human factors to desertification [6,50-55]. The quantitative decoupling of desertification drivers is usually undertaken 
through methods such as modeling, correlation analysis, regression analysis, and principal component analysis. To date, such studies are seldomly undertaken in Mongolia, which limits the quantitative research on the contribution of different factors and the understanding of driving mechanisms of desertification. Some studies, however, have been conducted in other regions of the world, providing a useful reference for the decoupling research in Mongolia. For example, Zhang et al. [50] established a multi-factor equation for desertification of modern grassland in Guinan, Qinghai, which lies in the arid and semi-arid regions, and calculated the contribution rates of different factors of desertification from the perspective of wind erosion. Li et al. [55] proposed a mutual feedback model between the change in quicksand area and the change in vegetation coverage to quantitatively study the contribution rates of natural factors to modern desertification in Inner Mongolia, which is also a part of the Mongolian Plateau. Feng et al. [6] used a pooled regression model to analyze the impacts of climate change and human activities on desertification in China. The decoupling study of driving factors should become one of the key points in Mongolia's desertification research.

Table 1. Driving factors of the desertification in Mongolia.

\begin{tabular}{|c|c|c|c|c|c|}
\hline $\begin{array}{l}\text { Serial } \\
\text { Number }\end{array}$ & Natural Factors & Human Factors & Study Area & Study Phase & $\begin{array}{c}\text { Source/ } \\
\text { Reference }\end{array}$ \\
\hline 1 & $\begin{array}{l}\text { 1. Global warming (the average } \\
\text { temperature in Mongolia has risen } \\
\text { by } 1.5-2.5^{\circ} \mathrm{C} \text { in the past } 40 \text { years, } \\
\text { which is } 2.3 \text { times the global } \\
\text { average level) } \\
\text { 2. Increasing climate change (the } \\
\text { temperature in Mongolia increased } \\
\text { significantly after } 1989 \text {, and the } \\
\text { rainfall decreased significantly } \\
\text { after 1995) }\end{array}$ & $\begin{array}{l}\text { 1. Overgrazing (the number of } \\
\text { livestock increased rapidly } \\
\text { after 1990) } \\
\text { 2. Herd structure disorders (the } \\
\text { proportion of goats continues } \\
\text { to increase) } \\
\text { 3. Unplanned use of pasture } \\
\text { 4. Mineral mining (lack of recovery } \\
\text { work after mining) } \\
\text { 5. Excessive felling of trees }\end{array}$ & Mongolia & 1961-2009 & [19] \\
\hline 2 & & $\begin{array}{l}\text { 1. Herdsmen focus on pursuing } \\
\text { economic interests and ignore } \\
\text { grassland protection awareness } \\
\text { 2. Unscientific development and } \\
\text { utilization of natural resources } \\
\text { (such as mineral resources) } \\
\text { 3. Incomplete laws and regulations } \\
\text { related to grassland } \\
\text { ecological protection }\end{array}$ & $\begin{array}{l}\text { Mongolia and } \\
\text { Inner Mongolia }\end{array}$ & & [28] \\
\hline 3 & $\begin{array}{l}\text { 1. The impact of climate change: } \\
\text { temperature increased; precipitation } \\
\text { decreased (since the 1990s) } \\
\text { 2. The impact of the disaster: fire }\end{array}$ & $\begin{array}{l}\text { 1. The impact of policies, laws } \\
\text { and regulations } \\
\text { 2. Population growth (1992-2005) }\end{array}$ & Mongolia & 1992-2005 & [34] \\
\hline 4 & $\begin{array}{l}\text { 1. Precipitation is generally low } \\
\text { throughout Mongolia } \\
\text { 2. High winds } \\
\text { 3. Water depletion (some lakes in } \\
\text { southern Mongolia have been } \\
\text { severely depleted or dried out) }\end{array}$ & $\begin{array}{c}\text { 1. Overgrazing } \\
\text { 2. Deforestation } \\
\text { 3. Road erosion (vehicles) } \\
\text { 4. Mineral mining and inadequate } \\
\text { waste management }\end{array}$ & Mongolia & & [42] \\
\hline 5 & $\begin{array}{l}\text { Climate change (in the past } 40 \text { years, } \\
\text { the temperature in Mongolia has } \\
\text { risen significantly, and the } \\
\text { precipitation in the southern and } \\
\text { central regions has decreased) }\end{array}$ & $\begin{array}{l}\text { 1. Overgrazing } \\
\text { 2. Changes in herd structure and } \\
\text { excessive trampling } \\
\text { 3. Grazing system (seasonal and } \\
\text { fixed-point grazing) }\end{array}$ & $\begin{array}{l}\text { Mongolia: } \\
\text { Sukhbaatar } \\
\text { and Khentii }\end{array}$ & $\begin{array}{l}18 \text { June } \\
\text { 2016-20 June } \\
2016 \text { (Field } \\
\text { investigation) }\end{array}$ & {$[43]$} \\
\hline 6 & $\begin{array}{l}\text { 1. Temperature } \\
\text { 2. Precipitation } \\
\text { 3. High winds (Sukhbaatar is one of } \\
\text { the windiest areas in Mongolia) }\end{array}$ & $\begin{array}{l}\text { Overgrazing (the livestock number } \\
\text { is too large to implement the district } \\
\text { rotation grazing system) }\end{array}$ & $\begin{array}{l}\text { Mongolia: } \\
\text { Sukhbaatar }\end{array}$ & & {$[44]$} \\
\hline
\end{tabular}


Table 1. Cont.

\begin{tabular}{|c|c|c|c|c|c|}
\hline $\begin{array}{c}\text { Serial } \\
\text { Number }\end{array}$ & Natural Factors & Human Factors & Study Area & Study Phase & $\begin{array}{c}\text { Source/ } \\
\text { Reference }\end{array}$ \\
\hline 7 & Global warming & $\begin{array}{l}\text { 1. Mineral mining (the peak period } \\
\text { of mining land degradation } \\
\text { occurred from } 1995 \text { to 2008) } \\
\text { 2. Road erosion } \\
\text { 3. Overgrazing } \\
\text { 4. Agricultural soil erosion (central } \\
\text { and eastern agricultural regions } \\
\text { of Mongolia) } \\
\text { 5. Deforestation } \\
\text { 6. Soil pollution (mainly occurs in } \\
\text { big cities, especially in Ulaanbaatar, } \\
\text { the capital city of Mongolia) }\end{array}$ & Mongolia & Before 2010 & [45] \\
\hline 8 & $\begin{array}{l}\text { 1. The climate is harsh and there are } \\
\text { more winds } \\
\text { 2. The soil is easily eroded by wind }\end{array}$ & $\begin{array}{l}\text { 1. Overgrazing (in Sukhbaatar, too } \\
\text { many livestock to implement the } \\
\text { rotational grazing system) } \\
\text { 2. The herd ratio is unreasonable, } \\
\text { and the goat ratio is increasing } \\
\text { 3. Mining industry (companies } \\
\text { destroy vegetation during } \\
\text { exploration, drilling and mining) }\end{array}$ & $\begin{array}{c}\text { Mongolia: } \\
\text { Sukhbaatar, } \\
\text { Inner } \\
\text { Mongolia: } \\
\text { Xilingol } \\
\text { League }\end{array}$ & & [46] \\
\hline 9 & $\begin{array}{l}\text { Decrease in precipitation and } \\
\text { increase in temperature are the } \\
\text { main causes of vegetation } \\
\text { degradation in Mongolia }\end{array}$ & $\begin{array}{l}\text { Human factors such as animal } \\
\text { husbandry and land cultivation } \\
\text { have increased the impact of climate } \\
\text { factors and promoted desertification }\end{array}$ & Mongolia & 1982-2016 & [47] \\
\hline 10 & $\begin{array}{l}\text { Climate change (changes in } \\
\text { precipitation and temperature) }\end{array}$ & $\begin{array}{l}\text { The main factors of vegetation } \\
\text { change in Mongolia are human } \\
\text { factors, including farmland } \\
\text { cultivation and grazing }\end{array}$ & $\begin{array}{l}\text { A small lake in } \\
\text { central } \\
\text { Mongolia } \\
\text { (Lake M0-33B) }\end{array}$ & 1950-2005 & [48] \\
\hline 11 & $\begin{array}{l}\text { 1. Precipitation (Precipitation } \\
\text { changes are volatile, but the overall } \\
\text { trend is decreasing) } \\
\text { 2. Temperature (increasing trend) }\end{array}$ & $\begin{array}{c}\text { 1. From } 2000 \text { to } 2014 \text {, the population } \\
\text { of Mongolia increased } \\
\text { 2. The number of livestock } \\
\text { has increased }\end{array}$ & $\begin{array}{l}\text { China- } \\
\text { Mongolia } \\
\text { border area } \\
\quad \text { (east) }\end{array}$ & 2000-2015 & [56] \\
\hline 12 & $\begin{array}{c}\text { From } 2000 \text { to } 2015 \text {, the temperature } \\
\text { increased and the } \\
\text { precipitation decreased }\end{array}$ & $\begin{array}{l}\text { 1. Overgrazing (especially an } \\
\text { increase in the number of goats) } \\
\text { 2. Infrastructure construction } \\
\text { accelerates the process of land } \\
\text { degradation } \\
\text { 3. Unreasonable mineral mining in } \\
\text { Southern Mongolia } \\
\text { 4. Rapid urbanization leads to } \\
\text { increased risks of land degradation }\end{array}$ & $\begin{array}{l}\text { Along the } \\
\text { China- } \\
\text { Mongolia } \\
\text { Railway } \\
\text { (Mongolia } \\
\text { section) }\end{array}$ & 1990-2015 & [57] \\
\hline
\end{tabular}

\subsection{Prevention Measures of Desertification}

The prevention and control of desertification is crucial for the realization of sustainable development on a global scale. In line with this, how to mitigate and prevent desertification more effectively has become a research focus in the field of ecology and environment [11]. In Mongolia, desertification has not yet reached the state of irreversibility [58]. However, in sparsely vegetated areas, the loss of vegetation coverage has continued to aggravate desertification. If the process is not well controlled, desertification will become more severe and reach an irreversible state once the climate and/or human disturbance reaches a certain threshold [59,60]. It is thus necessary to prevent the desertification in Mongolia.

Since the 1990s, Mongolia has implemented a number of policies and measures (Table 2) to alleviate desertification. In 1996 Mongolia joined the United Nations Convention to Combat Desertification (UNCCD) and carried out the National Desertification Control Plan. In 2005, the National Desertification Control Committee was established, the Mongolian Green Great Wall Plan was launched, and since 2008 the enhanced land reclamation in mining areas was implemented. Although these measures were expected to play a crucial role in preventing desertification, they did not work well mainly due 
to limited funds and lack of continuity $[28,43,45]$. For example, The Mongolian Green Great Wall Project (also known as Green Belt Eco-Strip National Program) was launched to establish approximately $3000 \mathrm{~km}$ of green belt in southern Mongolia [28]. However, the project lacked a prior environmental impact assessment and cost-benefit analysis and did not anticipate solutions for the possible consequences in advance. Therefore, it was implemented without good planning and management. Eventually, the survival rate of the planted saplings was low, and the expected functions of desertification control were not achieved [61].

To improve the effectiveness of desertification control in Mongolia, scholars have proposed more sustainable prevention measures. For example, in grassland grazing, proper grazing was advocated to avoid overgrazing and thus to relieve grassland degradation and desertification. The appropriate time for grazing activities in a camp was suggested to be 15-20 days. An adjustment to the grazing system and traditional nomadic feeding methods was also proposed $[19,27,28]$. In terms of government policy regulation, the enhancement of investment and a strengthening of the government's guiding and supervisory role was suggested. The suggestions also included (i) improvements to the legal system, (ii) a formulation and promulgation of relevant land protection policies and land management laws, and (iii) an adoption of compulsory measures to control land degradation. Some further suggestions were also given, including (i) an improvement of the social service system in pastoral areas and effective use of idle pastures to reduce the pressure on pastures in overgrazed areas, (ii) a vigorous development of the deep processing industry of animal husbandry products, (iii) an improvement of the upstream and downstream industrial chains, and (iv) a broadening of income sources for herders [19,28,45,62].

In addition, desertification monitoring should be strengthened, especially early warning monitoring of desertification [63]. Without the ability to predict ecological changes, it will be difficult to formulate sustainable management and restoration strategies for the ecosystem [60]. Early warning monitoring can be achieved through a modeling approach $[64,65]$. Furthermore, Mongolia and Inner Mongolia of China are both located on the Mongolian Plateau and thus feature similar ecological environments. Strengthening mutual cooperation and learning from each other in desertification prevention have been suggested [28].

Animal husbandry is the fundamental industry of Mongolia's national economy, and the development of animal husbandry should be taken into consideration when carrying out the desertification control. In the future, it will be necessary to accurately estimate their impacts on grassland biomass when desertification prevention measures are proposed. An in-depth study needs to be conducted to explore the relationship between grassland degradation/restoration and animal husbandry development. This will benefit a balanced development of ecological protection and animal husbandry.

Table 2. Desertification prevention measures in Mongolia.

\begin{tabular}{|c|c|c|c|c|c|}
\hline $\begin{array}{c}\text { Serial } \\
\text { Number }\end{array}$ & $\begin{array}{l}\text { Name of } \\
\text { Measures }\end{array}$ & Measures Content & $\begin{array}{c}\text { Implement } \\
\text { Time }\end{array}$ & Measures Evaluation & $\begin{array}{c}\text { Source/ } \\
\text { Reference }\end{array}$ \\
\hline 1 & $\begin{array}{c}\text { Pasture } \\
\text { management } \\
\text { model }\end{array}$ & $\begin{array}{l}\text { Co-management model } \\
\text { (based on the community, } \\
\text { forming a joint management } \\
\text { group composed of herdsmen, } \\
\text { and signing a formal joint } \\
\text { management agreement with } \\
\text { the government on the use of } \\
\text { pasture in the name of } \\
\text { the community). }\end{array}$ & $1990 \mathrm{~s}$ & $\begin{array}{l}\text { The co-management model is } \\
\text { of great significance because } \\
\text { herders are one of the most } \\
\text { important links in combating } \\
\text { desertification. Clarifying the } \\
\text { responsibilities and } \\
\text { obligations of herdsmen is the } \\
\text { key to combating grassland } \\
\text { desertification. }\end{array}$ & {$[28,43,66]$} \\
\hline
\end{tabular}


Table 2. Cont.

\begin{tabular}{|c|c|c|c|c|c|}
\hline $\begin{array}{l}\text { Serial } \\
\text { Number }\end{array}$ & $\begin{array}{l}\text { Name of } \\
\text { Measures }\end{array}$ & Measures Content & $\begin{array}{l}\text { Implement } \\
\text { Time }\end{array}$ & Measures Evaluation & $\begin{array}{c}\text { Source/ } \\
\text { Reference }\end{array}$ \\
\hline 2 & $\begin{array}{l}\text { Promulgate } \\
\text { relevant laws }\end{array}$ & $\begin{array}{l}\text { Mongolia promulgated the } \\
\text { "Forest Law" to standardize } \\
\text { forest protection, strengthen } \\
\text { forest regeneration and } \\
\text { restoration, and seek } \\
\text { sustainable development of } \\
\text { forest resources. }\end{array}$ & 1995 & $\begin{array}{l}\text { The promulgation of laws and } \\
\text { regulations will inhibit the } \\
\text { further degradation of forest } \\
\text { and slow down the } \\
\text { conversion of forest land to } \\
\text { unused land types. }\end{array}$ & [34] \\
\hline 3 & $\begin{array}{c}\text { Government } \\
\text { control measures }\end{array}$ & $\begin{array}{l}\text { The National Desertification } \\
\text { Control Plan was adopted, } \\
\text { Mongolia became a member } \\
\text { of the United Nations } \\
\text { Convention to Combat } \\
\text { Desertification (UNCCD), the } \\
\text { National Desertification } \\
\text { Control Committee was } \\
\text { established, and the action } \\
\text { plan, policies and education } \\
\text { actions for desertification } \\
\text { prevention and control have } \\
\text { been formulated. }\end{array}$ & 1996 & $\begin{array}{l}\text { Measures taken at the } \\
\text { government level } \\
\text { (government-led) have been } \\
\text { executed to a certain degree. } \\
\text { However, due to the limited } \\
\text { economic capacity of } \\
\text { Mongolia, the investment in } \\
\text { desertification control is still } \\
\text { insufficient. Therefore, the } \\
\text { effect of desertification control } \\
\text { is not very satisfactory. }\end{array}$ & [43] \\
\hline 4 & $\begin{array}{c}\text { Mongolia Green } \\
\text { Great Wall Project, } \\
\text { The North-South } \\
\text { Water Diversion } \\
\text { Project }\end{array}$ & $\begin{array}{l}\text { The Mongolian Green Great } \\
\text { Wall Project was funded by } \\
\text { the United Nations, the World } \\
\text { Bank and other institutions, } \\
\text { and a green belt of } \\
\text { approximately } 3000 \mathrm{~km} \text { from } \\
\text { east to west was built in } \\
\text { southern Mongolia. The } \\
\text { Mongolian "North-South } \\
\text { Water Diversion" project will } \\
\text { build three roads across } \\
\text { Mongolia. The estimated } \\
\text { length of the pipeline is } 500 \\
\text { km for the east line, } 1100 \mathrm{~km} \\
\text { for the middle line, and } 800 \\
\text { km for the west line. }\end{array}$ & 2005 & $\begin{array}{l}\text { A protective forest of } 705.98 \\
\mathrm{~km}^{2} \text { hectares has been } \\
\text { established, which has had a } \\
\text { certain effect on preventing } \\
\text { desertification in the southern } \\
\text { part of Mongolia. However, } \\
\text { the Mongolian North-South } \\
\text { Water Diversion Project is still } \\
\text { at the written stage, and the } \\
\text { lack of water has not been } \\
\text { resolved, which has also } \\
\text { affected the implementation } \\
\text { of the "Mongolia Green Great } \\
\text { Wall Plan." }\end{array}$ & {$[28,43]$} \\
\hline 5 & $\begin{array}{c}\text { Public awareness } \\
\text { measures }\end{array}$ & $\begin{array}{l}\text { In Mongolia, the second } \\
\text { Saturdays in May and October } \\
\text { are designated as "National } \\
\text { Tree Planting Day" every year. }\end{array}$ & 2015 & $\begin{array}{l}\text { This measure will strengthen } \\
\text { the promotion of } \\
\text { desertification prevention and } \\
\text { control activities and } \\
\text { encourage people across the } \\
\text { country to actively participate } \\
\text { in tree planting activities to } \\
\text { prevent desertification. }\end{array}$ & {$[44]$} \\
\hline
\end{tabular}

\subsection{Research Methods of Desertification}

Desertification research methods in Mongolia generally include field investigation, experimental manipulations, remote sensing monitoring, and modeling approaches (Table 3 ). The field investigation is conducted through field inspections in the research area to collect relevant data. It is often used for small-scale research and to verify the results of remote sensing interpretation and model simulation. Liu et al. [43] surveyed desertification in Mongolia's Sukhbaatar and Khentii provinces to study the types and development of desertification there. Sternberg et al. [58] investigated desertification changes in Mongolia through field investigations and remote sensing monitoring. They found that field 
investigation was a useful way of improving the accuracy of remote sensing monitoring in sparsely vegetated areas. In addition, in the research conducted by Wang et al. [20,30] on land cover and land degradation patterns in Mongolia, field sampling data were employed to verify the interpretation results of remote sensing images.

The experimental methods of desertification research in Mongolia mainly include radionuclide sedimentation technology, isotope tracing, and soil erosion experiments $[45,48,59]$. For example, Onda et al. [59] conducted the first sediment production and transport experiments in Mongolia to study vegetation degradation and associated erosion processes. Radionuclide tracking technology was also employed to conduct an in-depth research on erosion processes and their driving mechanism.

Remote sensing data have often been used to study the spatiotemporal characteristics of desertification in Mongolia [20,23,30,32,57,67] and the determination of desertification hotspots [33]. The indices derived from remote sensing data have been used to study the relationship between desertification and influencing factors. Vegetation index and drought index can be used to explore the impact of climate on desertification [68]. A comprehensive use of vegetation index, surface soil particle size index, and topographic wetness index is helpful for studies on the relationship between desertification and environmental changes $[69,70]$.

The modeling approach refers to the prediction and evaluation of desertificationrelated indicators through the establishment and/or application of models. Previous modeling studies on Mongolian desertification mostly used models that were originally developed in other regions, such as the grassland biomass model and the desertification assessment model (MEDLUS) [71]. However, few models have been initially developed for desertification in Mongolia. Grassland biomass change is an important indicator of grassland degradation and restoration, and accurate biomass estimation is a prerequisite for an improved understanding of vegetation degradation [72]. Li et al. [73,74] established three models for estimating grassland production based on the Normalized Difference Vegetation Index (NDVI), Enhanced Vegetation Index (EVI), Modified Soil Adjusted Vegetation Index (MSAVI), and Net Photosynthesis (PsnNet), and then they selected the optimal model, which was developed based on the MSAVI index. However, the model was only applied to six provinces of central and eastern Mongolia and the Mongolian part of the China-Mongolia Railway; it was not used to estimate the grassland production status for the whole of Mongolia [73,74]. Lee et al. [75] employed the MEDLUS model to calculate the environmental sensitive area index (ESAI) and its spatial distribution throughout Mongolia. However, owing to the lack of available data, this study was conducted at a rather low spatial resolution $(55 \mathrm{~km})$ [75].

Field surveys are costly and time-consuming and are suitable for small-scale survey sampling. However, they can obtain the most direct and accurate records, which are normally used to verify modeling and remote sensing interpretation results. Remote sensing methods are suitable for a long-term dynamic monitoring of large-scale desertification, but the accuracy (especially in areas with sparse vegetation) still needs improvements. The experimental method is able to simulate the desertification process and is suitable for studying desertification mechanisms. The research results are only applicable to a local scale, and difficult to extend to a large area. The model method is capable of predicting the changing trend of desertification and is suitable for the study of spatiotemporal changes in desertification. Some interdisciplinary models (such as a mathematical model describing the dynamics of water-limited vegetation in drylands and dynamics in bistable systems) are capable of studying the state of desertification [76-78]. A timely monitoring of the state of desertification will be largely beneficial for the development and implementation of prevention measures before the desertification reaches an irreversible state. However, model development and application require a large amount of data and an in-depth cooperation between different research communities, constraining the development of desertification models for Mongolia. 
In short, different research methods are suitable for different scales of research questions, and a combination of different methods is conducive to the development of multiscale research on desertification. In addition, the interdisciplinary approach is beneficial for the desertification study in Mongolia as it combines knowledge and skills from different fields to facilitate a cutting-edge research.

Table 3. Research methods for desertification in Mongolia.

\begin{tabular}{|c|c|c|c|c|c|c|}
\hline $\begin{array}{c}\text { Serial } \\
\text { Number }\end{array}$ & $\begin{array}{l}\text { Research } \\
\text { Method }\end{array}$ & $\begin{array}{l}\text { Application } \\
\text { of Scale }\end{array}$ & Advantage & Disadvantage & Applicable Direction & $\begin{array}{c}\text { Source/ } \\
\text { Reference }\end{array}$ \\
\hline 1 & $\begin{array}{l}\text { Field } \\
\text { investigation } \\
\text { method }\end{array}$ & Small & $\begin{array}{l}\text { Makes the abstract } \\
\text { landscape concrete and } \\
\text { records the results } \\
\text { accurately. }\end{array}$ & $\begin{array}{l}\text { If the field sampling is } \\
\text { repeated, the cost is } \\
\text { high and long-term } \\
\text { dynamic monitoring } \\
\text { cannot be performed. }\end{array}$ & $\begin{array}{l}\text { Desertification survey, } \\
\text { field sample survey to } \\
\text { verify remote sensing } \\
\text { monitoring accuracy }\end{array}$ & {$[43,58,79]$} \\
\hline 2 & $\begin{array}{l}\text { Experimental } \\
\text { method }\end{array}$ & Small & $\begin{array}{l}\text { Has more in-depth } \\
\text { research on the process } \\
\text { and mechanism of } \\
\text { desertification. }\end{array}$ & $\begin{array}{c}\text { The experiment process } \\
\text { is complicated and } \\
\text { labor-intensive. }\end{array}$ & $\begin{array}{l}\text { Research on the } \\
\text { mechanism of } \\
\text { desertification }\end{array}$ & {$[45,59]$} \\
\hline 3 & $\begin{array}{l}\text { Remote sensing } \\
\text { method }\end{array}$ & Middle, large & $\begin{array}{l}\text { Large-scale and } \\
\text { long-term series } \\
\text { analysis can be carried } \\
\text { out for dynamic } \\
\text { monitoring and various } \\
\text { vegetation indexes can } \\
\text { be used for more } \\
\text { abundant research (such } \\
\text { as drought monitoring, } \\
\text { grassland biomass } \\
\text { monitoring). }\end{array}$ & $\begin{array}{l}\text { In dryland areas, the } \\
\text { accuracy of estimating } \\
\text { vegetation coverage in } \\
\text { sparsely vegetated areas } \\
\text { based only on remote } \\
\text { sensing images is low. }\end{array}$ & $\begin{array}{l}\text { Long-term dynamic } \\
\text { monitoring of } \\
\text { desertification }\end{array}$ & {$[20,58,69]$} \\
\hline 4 & Model method & Middle, large & $\begin{array}{l}\text { Quickly evaluates the } \\
\text { intensity of } \\
\text { desertification under } \\
\text { different scenarios, and } \\
\text { then analyzes the } \\
\text { impact and contribution } \\
\text { of different factors on } \\
\text { desertification. }\end{array}$ & $\begin{array}{l}\text { The amount of data } \\
\text { required for model } \\
\text { parameters is large, and } \\
\text { when the study area } \\
\text { changes, the model } \\
\text { needs to be modified to } \\
\text { fit the new study area. }\end{array}$ & $\begin{array}{c}\text { Forecasting } \\
\text { desertification } \\
\text { development trends, } \\
\text { desertification } \\
\text { spatiotemporal } \\
\text { changes and driving } \\
\text { mechanism research }\end{array}$ & {$[73-75]$} \\
\hline
\end{tabular}

\section{Conclusions and Prospects}

This paper systematically reviewed the recent progress made in Mongolia's desertification and prevention in terms of spatiotemporal distribution, driving factors, prevention measures, and research methods. Current progress of the research and future research directions are summarized as below.

(1) Previous studies have extensively studied the spatial pattern of desertification in Mongolia, with some of them showing a gradual increase of desertification from northeast to southwest Mongolia. Remote sensing data have been widely applied in the desertification monitoring in Mongolia. However, the spatial resolution of the remote sensing data used is generally low. In addition, the timely desertification monitoring results and associated data products are also lacking. These limit the accuracy of remote sensing monitoring results and an in-depth process understanding of desertification. Therefore, high-resolution and timely data products are needed in the future for desertification monitoring, vegetation change analysis, and grassland biomass estimation.

(2) Mongolia's desertification is the result of the combined effects of natural and human factors, and the qualitative analysis of the driving factors has been well developed. However, quantitative research is still lacking. This has constrained the understanding of driving mechanisms for Mongolia's desertification and the proposal of appropriate desertification prevention measures. Follow-up research needs to strengthen the decoupling analysis of each driving factor and a quantitative analysis of the relative contributions 
of different factors to desertification in different regions of Mongolia. Such studies will provide a direct reference for desertification prevention and control measures.

(3) Mongolia has implemented a number of policy measures to prevent desertification. However, some projects lacked planning, management, and financial support, and the expected effects of desertification prevention and control have not been achieved. In the future, according to the actual situation in Mongolia, the relationship between grassland changes and animal husbandry development should be well considered when formulating desertification prevention measures in order to achieve a balance between ecological protection and animal husbandry.

(4) Contemporary studies have mainly used field surveys, experimental methods, remote sensing methods, and modeling methods to study desertification in Mongolia. Different methods are suitable for different research scales and problems. A joint application of multiple methods and, in particular, an interdisciplinary approach should be strengthened. In addition, desertification models, particularly those on a fine scale, are severely lacking in Mongolia, which needs to be addressed in the future.

Author Contributions: P.L. and J.W. conceived the idea and designed the research. X.L., P.L. and J.W. wrote the manuscript. F.K.S.C., C.T., A.O. and D.D. reviewed and refined the manuscript. All authors have read and agreed to the published version of the manuscript.

Funding: This research was supported by the National Natural Science Foundation of China (grant numbers 41971385, 41807063, and 41977059); Construction Project of China Knowledge Center for Engineering Sciences and Technology, No. CKCEST-2021; and National University of Mongolia, grant number P2020-3779.

Institutional Review Board Statement: Not applicable.

Informed Consent Statement: Not applicable.

Data Availability Statement: Not applicable.

Acknowledgments: The authors fully appreciate the funding that supported this study, which makes this important research viable and effective.

Conflicts of Interest: The authors declare no conflict of interest.

\section{References}

1. Cheng, L.; Lu, Q.; Wu, B.; Yin, C.; Bao, Y.; Gong, L. Estimation of the costs of desertification in China: A critical review. Land Degrad. Dev. 2018, 29, 975-983. [CrossRef]

2. Reynolds, J.F.; Smith, D.M.S.; Lambin, E.F.; Turner, B.; Mortimore, M.; Batterbury, S.P.; Downing, T.E.; Dowlatabadi, H.; Fernández, R.J.; Herrick, J.E. Global desertification: Building a science for dryland development. Science 2007, 316, 847-851. [CrossRef] [PubMed]

3. Lal, R. Soil erosion and land degradation: The global risks. In Advances in Soil Science; Springer: Berlin/Heidelberg, Germany, 1990; pp. 129-172.

4. Dong, J.; Chen, S.Y.; Yang, D.Y. Progress and prospect of land degradation research. J. Liaocheng Univ. 2008, $21,23-29$.

5. Wang, X.; Chen, F.; Hasi, E.; Li, J. Desertification in China: An assessment. Earth Sci. Rev. 2008, 88, 188-206. [CrossRef]

6. Feng, Q.; Ma, H.; Jiang, X.; Wang, X.; Cao, S. What has caused desertification in China? Sci. Rep. 2015, 5, 15998. [CrossRef]

7. Meng, X.C. A Study on the Impact of Mongolian Sandy Desertification on Sandy Desertification in Northern China; Jilin University: Changchun, China, 2012.

8. Xing, Y.Q.; Guo, X.H. The Present Situation and Countermeasures of Land Desertification-Written on the occasion of the arrival of the 16th National Land Day. Henan Land Resour. 2006, 6, 26.

9. Xie, H.; Guo, H. Research progress in desertification Monitoring and evaluation indicators system. World For. Res. 2015, 28 , 7-11.

10. Zhao, Y.Y.; Gao, G.L.; Qin, S.G.; Yu, M.H.; Ding, G.D. Desertification detection and the evaluation indicators: A review. J. Arid. Land Resour. Environ. 2019, 33, 81-87.

11. Zhu, L.; Zhu, W.L. Domestic and overseas review of land desertification control and ecological restoration. J. Hum. Settl. West China 2020, 35, 97-103.

12. Zhao, J.X. The situation of desertification at home and abroad and sand prevention and control in Tibet. For. Constr. 2007, 1, 25-28.

13. Desa, U. Transforming our World: The 2030 Agenda for Sustainable Development; Department of Economic and Social Affairs: New York, NY, USA, 2016. 
14. Zhang, Z.F. Sustainable land use goals, challenges and countermeasures for SDGs. China Land Sci. 2019, 33, 48-55.

15. Kosmas, C.; Kairis, O.; Karavitis, C.; Ritsema, C.; Salvati, L.; Acikalin, S.; Alcalá, M.; Alfama, P.; Atlhopheng, J.; Barrera, J. Evaluation and selection of indicators for land degradation and desertification monitoring: Methodological approach. Environ. Manag. 2014, 54, 951-970. [CrossRef] [PubMed]

16. Huang, J.; Yu, H.; Guan, X.; Wang, G.; Guo, R. Accelerated dryland expansion under climate change. Nat. Clim. Chang. 2015, 6, 166-171. [CrossRef]

17. Zhou, R.P. Desertification regionalization and spatiotemporal evolution in China. J. Geo-Inf. Sci. 2019, 21, 675-687.

18. Liu, S.J.; Ochir, A.; Liu, H.J.; Liu, K.L.; Li, J.J.; Wan, X.; Chen, F. Relationship between ecological environment and desertification in Mongolia. Inn. Mong. Sci. Technol. Econ. 2020, 444, 56-57, 59.

19. Buren, G.W. A Study on Desertification Status, Causes and Prospect of Grassland Animal Husbandry in Mongolia; Inner Mongolia University: Hohhot, China, 2011.

20. Wang, J.; Wei, H.; Cheng, K.; Ochir, A.; Davaasuren, D.; Li, P.; Chan, F.K.S.; Nasanbat, E. Spatio-Temporal Pattern of Land Degradation from 1990 to 2015 in Mongolia. Environ. Dev. 2020, 34, 100497. [CrossRef]

21. Chen, F.; Liu, H.J.; Liu, S.J.; Ochir, A. Modis-based desertification dynamic monitoring in Mongolia from 2003 to 2017. J. Northwest For. Univ. 2019, 34, 167-171.

22. Nearly $80 \%$ of Mongolia's Land is Suffering from Desertification of Varying Degrees. Available online: http://world.people.com. cn/n1/2017/0617/c1002-29345905.html (accessed on 10 March 2020).

23. Eckert, S.; Hüsler, F.; Liniger, H.; Hodel, E. Trend analysis of MODIS NDVI time series for detecting land degradation and regeneration in Mongolia. J. Arid. Environ. 2015, 113, 16-28. [CrossRef]

24. Wang, J.L.; Cheng, K.; Zhu, J.X.; Liu, Q. Development and spatial pattern analysis of land cover products with a resolution of 30 $\mathrm{m}$ in Mongolia. J. Geo-Inf. Sci. 2018, 20, 1263-1273.

25. Forage, P. Secuestro de Carbono en Tierras Aridas; FAO: Rome, Italy, 2007; pp. 9-15.

26. Ling, Z. Study on Soil Type Distribution and Crop Industry Development in Mongolia; Inner Mongolia Normal University: Hohhot, China, 2017.

27. Li, Y.F.; Wang, J.L.; Zhu, J.X. Landscape pattern analysis of Mongolia based on geographical partition. Arid. Land Geogr. 2016, 39, 817-827.

28. Bai, W.Y.; Jin, L. Comparative study on grassland ecological environment problems and solutions between Mongolia and Inner Mongolia. Econ. Forum 2015, 5, 18-21.

29. Shi, H.D.; Zhou, X.Y.; Meng, F.H.; Bai, H.M. The LUCC region of Mongolia and Inner Mongolia has been differentiated for 30 years. J. Earth Inf. Sci. 2013, 15, 719-725.

30. Wang, J.; Cheng, K.; Liu, Q.; Zhu, J.; Ochir, A.; Davaasuren, D.; Li, G.; Wei, H.; Chonokhuu, S.; Namsrai, O. Land cover patterns in Mongolia and their spatiotemporal changes from 1990 to 2010. Arab. J. Geosci. 2019, 12, 778. [CrossRef]

31. Liu, Q.; Liu, G.; Huang, C. Monitoring desertification processes in Mongolian Plateau using MODIS tasseled cap transformation and TGSI time series. J. Arid. Land 2018, 10, 12-26. [CrossRef]

32. Sa, R.; Yin, S.; Bao, Y.; Bao, H. Change of Desertification based on MODIS Data in the Mongolia Border Region. In Proceedings of the 7th Annual Meeting of Risk Analysis Council of China Association for Disaster Prevention (RAC-2016), Changsha, China, 4-6 November 2016.

33. Nasanbat, E.; Sharav, S.; Sanjaa, T.; Lkhamjav, O.; Magsar, E.; Tuvdendorj, B. Frequency analysis of MODIS NDVI time series for determining hotspot of land degradation in Mongolia. Int. Arch. Photogramm. Remote Sens. Spat. Inf. Sci. 2018, 42, 1299-1304. [CrossRef]

34. Wei, Y.J.; Zhen, L.; Liu, X.L.; Batkhishig, O. Land use change and its driving factors in Mongolia from 1992 to 2005. Chin. J. Appl. Ecol. 2008, 19, 1995-2002.

35. Gantumur, B.; Wu, F.; Vandansambuu, B.; Munaa, T.; Itiritiphan, F.; Zhao, Y. Land Degradation Assessment of Agricultural Zone and Its Causes: A Case Study in Mongolia. Remote Sens. Agric. Ecosyst. Hydrol. 2018, 107831W. [CrossRef]

36. Han, K.S.; Park, Y.Y.; Yeom, J.M. Detection of change in vegetation in the surrounding desert areas of Northwest China and Mongolia with multi-temporal satellite images. Asia Pac. J. Atmos. Sci. 2015, 51, 173-181. [CrossRef]

37. Miao, L.; Ye, P.; He, B.; Chen, L.; Cui, X. Future climate impact on the desertification in the dry land Asia using AVHRR GIMMS NDVI3g data. Remote Sens. 2015, 7, 3863-3877. [CrossRef]

38. Angerer, J.; Han, G.; Fujisaki, I.; Havstad, K. Climate change and ecosystems of Asia with emphasis on Inner Mongolia and Mongolia. Rangelands 2008, 30, 46-51. [CrossRef]

39. Xue, Y. The impact of desertification in the Mongolian and the Inner Mongolian grassland on the regional climate. J. Clim. 1996, 9 , 2173-2189. [CrossRef]

40. Xue, Y.; Shukla, J. The influence of land surface properties on Sahel climate. Part 1: Desertification. J. Clim. 1993, 6, 2232-2245. [CrossRef]

41. Xue, Y.; Fennessy, M.J.; Sellers, P.J. Impact of vegetation properties on US summer weather prediction. J. Geophys. Res. Atmos. 1996, 101, 7419-7430. [CrossRef]

42. Batjargal, Z. Desertification in Mongolia; RALA Report; National Agency for Meteorology, Hydrology and Environment Monitoring: Ulaanbaatar, Mongolia, 1997; Volume 200, pp. 107-113. 
43. Liu, S.J.; Liu, H.J.; Liu, K.L.; Li, J.J.; Wan, X.; Chen, F.; Ochir, A.; Mijidsuren, B.; Enkhbold, N.; Tseweendorj, D. Desertification survey for Sukhbaatar and Kent Provinces of Mongolia. West. Resour. 2018, 4, 183-186.

44. Su, R.S.G. Study on Desertification Status and Countermeasures of Sukhbato Province, Mongolia; Inner Mongolia University: Hohhot, China, 2015.

45. Batkhishig, O. Report of a Synthesis Workshop on Dryland Ecosystems in East Asia; Land Dynamics amid Social and Climate Change. In Human Impact and Land Degradation of Mongolia; The Higher Education Press: Beijing, China, 2011.

46. Liu, H.J.; Liu, S.J.; Liu, K.L.; Li, J.J.; Wan, X.; Chen, F.; Ochir, A.; Mijidsuren, B. Comparison of causes of desertification between Xilingol League of Inner Mongolia and Sukhbator Province of Mongolia. Inn. Mong. Sci. Technol. Econ. 2018, 24, 57-58, 60.

47. Filei, A.; Slesarenko, L.; Boroditskaya, A.; Mishigdorj, O. Analysis of Desertification in Mongolia. Russ. Meteorol. Hydrol. 2018, 43, 599-606. [CrossRef]

48. Tian, F.; Herzschuh, U.; Mischke, S.; Schlütz, F. What drives the recent intensified vegetation degradation in Mongolia-Climate change or human activity? Holocene 2014, 24, 1206-1215. [CrossRef]

49. Yang, Y.; Wang, Z.; Li, J.; Gang, C.; Zhang, Y.; Zhang, Y.; Odeh, I.; Qi, J. Comparative assessment of grassland degradation dynamics in response to climate variation and human activities in China, Mongolia, Pakistan and Uzbekistan from 2000 to 2013. J. Arid. Environ. 2016, 135, 164-172. [CrossRef]

50. Zhang, C.L.; Dong, G.R.; Zou, X.Y.; Cheng, H.; Yang, S. The contribution rate of desertification affecting factors in Guizhou south grassland. J. Desert Res. 2005, 25, 511-518.

51. Jia, B.Q.; Ci, L.J.; Gao, Z.G.; Zhang, H.Q. Quantitative analysis of natural and human factors in the process of land desertification in Ordos Plateau. Sci. For. 2003, 39, 15-20.

52. Jiang, Z.R.; An, L.; Chai, C.W. Quantitative analysis of desertification influencing factors in Minqin County. J. Desert Res. 2008, 28, 35-38.

53. Luo, X.X.; Yang, J.Q. Quantitative analysis of the role of humanity in desertification system based on GIS. Resour. Environ. Arid. Reg. 2005, 19, 30-34.

54. Zhang, D.S. Quantitative analysis of land desertification influencing factors in Gonghe Basin, Qinghai. J. Desert Res. 2000, 20, 60-63.

55. Li, Z.S.; He, L.M.; Wang, T. A method to determine the contribution rate of natural factors in modern grassland desertification. J. Desert Res. 2006, 26, 687-692.

56. Sa, R.L. Analysis of Desertification Change in China-Mongolia Border Area Based on Landsat TM Data; Inner Mongolia Normal University: Hohhot, China, 2017.

57. Wang, J.; Wei, H.; Cheng, K.; Li, G.; Ochir, A.; Bian, L.; Davaasuren, D.; Chonokhuu, S.; Nasanbat, E. Spatio-Temporal Pattern of Land Degradation along the China-Mongolia Railway (Mongolia). Sustainability 2019, 11, 2705. [CrossRef]

58. Sternberg, T.; Tsolmon, R.; Middleton, N.; Thomas, D. Tracking desertification on the Mongolian steppe through NDVI and field-survey data. Int. J. Digit. Earth 2011, 4, 50-64. [CrossRef]

59. Onda, Y.; Kato, H.; Tanaka, Y.; Tsujimura, M.; Davaa, G.; Oyunbaatar, D. Analysis of runoff generation and soil erosion processes by using environmental radionuclides in semiarid areas of Mongolia. J. Hydrol. 2007, 333, 124-132. [CrossRef]

60. Rietkerk, M.; Dekker, S.C.; De Ruiter, P.C.; van de Koppel, J. Self-organized patchiness and catastrophic shifts in ecosystems. Science 2004, 305, 1926-1929. [CrossRef]

61. Boldgiv, B.; Bayartogtokh, B.; Bayarsaikhan, U. Yellow dragon, green belt and alternative ecosystem states. Mong. J. Biol. Sci. 2005, 3, 49-58.

62. Ykhanbai, H.; Bulgan, E.; Beket, U.; Vernooy, R.; Graham, J. Reversing grassland degradation and improving herders' livelihoods in the Altai Mountains of Mongolia. Mt. Res. Dev. 2004, 24, 96-101. [CrossRef]

63. Kéfi, S.; Guttal, V.; Brock, W.A.; Carpenter, S.R.; Ellison, A.M.; Livina, V.N.; Seekell, A.D.; Scheffer, M.; Nes, E.H.; Dakos, V. Early Warning Signals of Ecological Transitions: Methods for Spatial Patterns. PLoS ONE 2014, 9, e92097. [CrossRef]

64. Dakos, V.; Kéfi, S.; Rietkerk, M.; Van Nes, E.H.; Scheffer, M. Slowing down in spatially patterned ecosystems at the brink of collapse. Am. Nat. 2011, 177, E153-E166. [CrossRef]

65. Bel, G.; Hagberg, A.; Meron, E. Gradual regime shifts in spatially extended ecosystems. Theor. Ecol. 2012, 5, 591-604. [CrossRef]

66. Ronnie, W. Joint management: Sustainable grassland paths in Mongolia. Resour. Hum. Settl. 2012, 1, 56-57.

67. Wei, H.; Wang, J.; Cheng, K.; Li, G.; Ochir, A.; Davaasuren, D.; Chonokhuu, S. Desertification Information Extraction Based on Feature Space Combinations on the Mongolian Plateau. Remote Sens. 2018, 10, 1614. [CrossRef]

68. Nanzad, L.; Zhang, J.; Tuvdendorj, B.; Nabil, M.; Zhang, S.; Bai, Y. NDVI anomaly for drought monitoring and its correlation with climate factors over Mongolia from 2000 to 2016. J. Arid. Environ. 2019, 164, 69-77. [CrossRef]

69. Lamchin, M.; Lee, J.-Y.; Lee, W.-K.; Lee, E.J.; Kim, M.; Lim, C.-H.; Choi, H.-A.; Kim, S.-R. Assessment of land cover change and desertification using remote sensing technology in a local region of Mongolia. Adv. Space Res. 2016, 57, 64-77. [CrossRef]

70. Lamchin, M.; Lee, W.-K.; Jeon, S.; Lee, J.-Y.; Song, C.; Piao, D.; Lim, C.; Khaulenbek, A.; Navaandorj, I. Correlation between desertification and environmental variables using remote sensing techniques in Hogno Khaan, Mongolia. Sustainability 2017, 9, 581. [CrossRef]

71. Kosmas, C.; Kirkby, M.J.; Geeson, N. The Medalus Project: Mediterranean Desertification and Land Use: Manual on Key Indicators of Desertification and Mapping Environmentally Sensitive Areas to Desertification; Directorate-General Science, Research and Development: Brussels, Belgium, 1999. 
72. Javzandulam, T.; Tateishi, R.; Sanjaa, T. Analysis of vegetation indices for monitoring vegetation degradation in semi-arid and arid areas of Mongolia. Int. J. Environ. Stud. 2005, 62, 215-225. [CrossRef]

73. Li, G.; Wang, J.; Wang, Y.; Wei, H.; Ochir, A.; Davaasuren, D.; Chonokhuu, S.; Nasanbat, E. Spatial and Temporal Variations in Grassland Production from 2006 to 2015 in Mongolia Along the China-Mongolia Railway. Sustainability 2019, 11, 2177. [CrossRef]

74. Li, G.; Wang, J.; Wang, Y.; Wei, H. Estimation of grassland production in central and eastern Mongolia from 2006 to 2015 via remote sensing. J. Resour. Ecol. 2019, 10, 676-684.

75. Lee, E.J.; Piao, D.; Song, C.; Kim, J.; Lim, C.H.; Kim, E.; Moon, J.; Kafatos, M.; Lamchin, M.; Jeon, S.W. Assessing environmentally sensitive land to desertification using MEDALUS method in Mongolia. For. Sci. Technol. 2019, 15, 210-220. [CrossRef]

76. Yizhaq, H.; Bel, G. Effects of quenched disorder on critical transitions in pattern-forming systems. New J. Phys. 2016, 18, 023004. [CrossRef]

77. Zelnik, Y.R.; Meron, E. Regime shifts by front dynamics. Ecol. Indic. 2018, 94, 544-552. [CrossRef]

78. Meron, E. Vegetation pattern formation: The mechanisms behind the forms. Phys. Today 2019, 72, 30-36. [CrossRef]

79. Zolotokrylin, A.; Bazha, S.; Titkova, T.; Syrtypova, S.-H. Trends in Livestock Numbers and Spectral Properties of the Pasture Surface: Case Study of the Middle Gobi Aimag of Mongolia. Arid. Ecosyst. 2018, 8, 153-160. [CrossRef] 